\title{
PROFIL SENYAW A POLAR TIGA JENIS MINYAK GORENG SELAMA PENGGORENGAN TAHU DAN TEMPE
}

\section{[The Polar Compound Profile of Three Types of Oil During Tofu and Tempeh Frying]}

\author{
Titri Siratantri Mastuti ${ }^{1) \star}$, Dedi Fardiaz ${ }^{2,3)}$, dan Didah Nur Faridah ${ }^{2,3)}$ \\ 1) Program Studi Teknologi Pangan, Universitas Pelita Harapan, Tangerang \\ 2) Departemen IImu dan Teknologi Pangan, Fakultas Teknologi Pertanian, Institut Pertanian Bogor, Bogor \\ ${ }^{3)}$ Southeast Asian Food and Agricultural Science and Technology (SEAFAST) Center, Institut Pertanian Bogor, Bogor
}

Diterima 30 Juli 2018 / Disetujui 22 Oktober 2018

\begin{abstract}
The quality of repeatedly used frying oil can be seen from its total polar material (TPM) content. This study aims to determine the influence of different types of oil with different degrees of unsaturation (coconut, palm, soybean oil) and foodstuffs with different characteristics (tofu and tempe) to the formation of the polar compounds in repeatedly used frying oil, based on the content of TPM, FFA, BI, FTIR and UV-Vis spectra. Chemical characterization of materials used was done in the first research stage. The second stage was the analysis of the polar compounds of the oil which was used for 3 hours/day for a dried of 15 hours. The results showed that the type of oil and food type affected the levels of TPM with increasing time of frying. The highest level of TPM $19.41 \pm 0.13 \%$ ob tained from combination soybean frying oil-tempeh (15 hours). The FTIR spectrum of the polar fraction from the used frying oil showed a large absorption in area $3600-3200 \mathrm{~cm}^{-1}$ wavelength in which hydroxyl groups indicate the polarity of the frying oil. The rate of increase of FFA in all combinations of oil type-tempeh was faster than combination oil type-tofu. Coconut oiltofu has a slower rate for FFA and browning index. The carbonyl compound in frying oil was showed from peak spectrum absorption at $420 \mathrm{~nm}$.
\end{abstract}

Keywords: FFA, tempeh, tofu, TPM, type of frying oil

\begin{abstract}
ABSTRAK
Kualitas minyak yang digunakan berulang kali untuk menggoreng bahan pangan dapat dilihat dari kandungan total senyawa polar (TPM) minyak goreng yang telah digunakan. Penelitian ini bertujuan untuk mengetahui pengaruh jenis minyak dengan derajat ketidakjenuhan yang berbeda (minyak kelapa, kelapa sawit, kedelai) dan bahan pangan dengan karakteristik berbeda (tahu dan tempe) terhadap pembentukan senyawa polar pada minyak yang digunakan berulang, dilihat dari kadar TPM, FFA, BI, spektrum FTIR dan UV-Vis. Tahap pertama penelitian dilakukan karakterisasi kimia bahan yang digunakan. Tahap kedua dilakukan analisis pem bentukan senyawa polar minyak yang digunakan berulang dengan total pemakaian minyak 15 jam dan selang penggorengan 3 jam per hari. Hasil penelitian menunjukkan jenis minyak dan bahan pangan mempengaruhi kadar TPM minyak dengan semakin lama waktu penggorengan. Kadar tertinggi TPM 19,41 $\pm 0,13 \%$ diperoleh dari minyak kedelai-tempe (15 jam). Spektrum FTIR fraksi polar minyak menunjukkan serapan besar pada $3600-3200 \mathrm{~cm}^{-1}$ sebagai gugus hidroksil yang menunjukkan kepolaran minyak goreng. Laju peningkatan kadar FFA lebih cepat pada semua kombinasi jenis minyaktempe dibandingkan kombinasi jenis minyak-tahu. Minyak kelapa-tahu mempunyai laju peningkatan FFA dan indek pencoklatan paling lambat. Terbentuknya senyawa karbonil pada minyak goreng ditunjukkan dengan adanya puncak absorbansi pada $420 \mathrm{~nm}$.
\end{abstract}

Kata kunci: FFA, jenis minyak goreng, tahu, tempe, TPM

\section{PENDAHULUAN}

Proses penggorengan menggunakan minyak nabati dengan suhu $150-190^{\circ} \mathrm{C}$ menimbulkan adanya kontak antara minyak, udara dan bahan pangan

${ }^{*}$ Penulis Korespondensi:

E-mail: titri.mastuti@uph.edu; dedi_fardiaz@yahoo.com.sg yang digoreng. Minyak dapat terdegradasi karena oksidasi, hidrolisis, polimerisasi selama penggorengan. Minyak goreng yang terdegradasi dapat memengaruhi mutu produk pangan. Minyak yang digunakan berulang sampai lima kali, menunjukkan terjadi kenaikan kadar asam lemak bebas pada minyak dan kentang yang digoreng (Tabee et al., 2009). 
Bahan pangan dengan kandungan nutrien berbeda dapat mempengaruhi komposisi minyak setelah penggorengan (Mariana et al., 2014). Tahu dan tempe banyak dikonsumsi masyarakat Indonesia. Berdasarkan data BPS (2018), selama 2014-2017 terjadi kenaikan konsumsi tahu $(0,136-0,157 \mathrm{~kg} /$ kapita/minggu) dan tempe $(0,133-0,147 \mathrm{~kg} / \mathrm{kapita} /$ minggu). Meskipun berasal dari bahan yang sama, tahu dan tempe memiliki karakteristik berbeda. Fermentasi kedelai menggunakan $R$. oligosporus membuat tempe memiliki daya cerna dan kadar asam amino yang tinggi (Rahmi et al., 2018). Kadar air tahu tinggi disebabkan adanya proses perebusan, penyaringan dan penggumpalan protein pada sari kedelai saat pengolahannya (Rizkaprilisa dan Setiadi, 2018). Air dari bahan pangan dapat memengaruhi hidrolisis minyak goreng selama penggorengan (Tarmizi, 2016).

Minyak kelapa sawit dan minyak kelapa biasa digunakan untuk menggoreng di Indonesia. Masyarakat Indonesia tidak memakai minyak kedelai untuk menggoreng namun masyarakat beberapa negara seperti Taiwan menggunakannya untuk menggoreng (Chen et al., 2013). Minyak kedelai mengandung asam lemak tidak jenuh 83,9\% (Hashem et al., 2017), sedangkan minyak goreng kelapa sawit mengandung 50,49\% (Fan et al., 2013). Minyak goreng kelapa tersusun dari banyak asam lemak jenuh dengan komponen utamanya asam laurat 49,74\% (Koh dan Long, 2012). Penelitian Halim et al. (2016) menunjukkan minyak kedelai untuk menggoreng tempe memiliki bilangan asam paling tinggi dibandingkan minyak kelapa sawit, minyak kelapa dan minyak jagung selama 15 batch (2 jam).

Selama penggorengan terjadi dekomposisi minyak membentuk senyawa alkohol, lakton, aldehida, keton, hidrokarbon aromatik, monoasilgliserol (MAG), diasilgliserol (DAG), triasilgliserol teroksida$\mathrm{si}$, triasilgliserol dimer, triasilgliserol polimer dan asam lemak bebas (FFA). Hasil dekomposisi tersebut disebut sebagai senyawa polar karena lebih polar dibandingkan TAG sebagai komponen utama minyak goreng. Analisis kadar TPM umumnya menggunakan metode pemisahan kromatografi kolom dan perhitungan berdasarkan berat komponen polar yang terpisah (Chen et al., 2013).

Semakin lama proses penggorengan, minyak semakin terdegradasi sehingga komponen polar semakin bertambah. Simposium Internasional Deep Frying VII merekomendasikan parameter terbaik untuk menilai mutu minyak goreng adalah kadar total polar material (TPM) dan polimer material (DGF, 2013). Beberapa negara Eropa seperti Prancis, Aus tria, Belgia, Jerman dan Spanyol sudah menerapkan regulasi kadar maksimum TPM minyak goreng yaitu 25\% (Li et al., 2016). Komponen polar seperti triasilgliserol dimer dan oligomer merupakan senyawa dengan berat molekul besar yang sulit dicerna oleh pancreatic lipase sehingga dapat meningkatkan risiko penyakit jantung dan saluran pencernaan pada orang yang mengkonsumsi makanan yang mengandung senyawa tersebut (Dobarganes dan MarquezRuiz, 2015).

Penelitian ini bertujuan untuk menentukan pengaruh jenis minyak goreng yang berbeda komposisi asam lemaknya dan perbedaan bahan pangan sumber protein nabati yang difermentasi dan tidak yaitu tempe dan tahu terhadap profil pembentukan senyawa polar pada minyak goreng selama penggorengan berulang dengan melihat parameter kadar TPM, FFA, indeks coklat minyak (BI), penyerapan spektrum UV-Vis dan FTIR. Minyak goreng yang digunakan adalah minyak kelapa (tinggi asam lemak jenuh), minyak kelapa sawit (asam lemak jenuh dan tidak jenuh seimbang) dan minyak kedelai (tinggi asam lemak tidak jenuh).

\section{BAHAN DAN METODE}

\section{Bahan}

Bahan untuk penelitian yaitu bahan untuk digoreng terdiri dari tahu dan tempe yang dibeli di City Market Citra Raya-Cikupa, minyak goreng komersial untuk menggoreng terdiri dari minyak goreng kelapa, minyak goreng kelapa sawit, minyak goreng kedelai yang dibeli di Supermarket di Tangerang.

\section{Proses penggorengan}

Proses penggorengan dilakukan berdasarkan metode Chen et al. (2013) dengan modifikasi. Minyak goreng segar dituang ke dalam fryer dan dipanaskan $\pm 170^{\circ} \mathrm{C}$. Setelah suhu tercapai dan dipertahankan selama 15 menit, tahu atau tempe yang telah dipotong dengan ukuran $2 \times 2 \times 1 \mathrm{~cm}$ digoreng dalam 2 Liter minyak selama 3 menit per siklus menggoreng. Rasio (bahan:minyak) yang digunakan adalah $(1: 20)$. Proses penggorengan dilakukan 3 jam per hari (27 siklus menggoreng) selama 5 hari (total 15 jam pemakaian minyak untuk menggoreng). Setelah 3 jam penggorengan, minyak diambil 100 gram dan disimpan dalam botol gelap untuk dianalisis. Sisa minyak di penggorengan ditutup dan didiamkan di suhu ruang semalaman. Penambahan minyak baru dilakukan setiap akan mulai penggorengan untuk mempertahankan rasio bahan:minyak (1:20).

Penelitian ini dilakukan menggunakan percobaan faktorial $(6 \times 6)$ dengan Rancangan Acak Lengkap (RAL). Faktor pertama yaitu kombinasi minyak dan bahan yang terdiri 6 level, yaitu minyak kelapa-tahu, minyak kelapa-tempe, minyak kelapa sawit-tahu, minyak kelapa sawit-tempe, minyak kedelai-tahu, minyak kedelai-tempe. Faktor kedua adalah lama pemakaian minyak goreng terdiri 6 level. Total lama pemakaian minyak untuk menggoreng adalah 15 jam dan analisis dilakukan pada pemakaian minyak 
tiap jam ke-0, 3, 6, 9, 12, 15. Proses penggorengan dilakukan dua kali ulangan. Parameter yang dianalisis adalah kadar TPM, FFA, BI. Data diolah dengan analisis ragam two-way ANOVA dilanjutkan dengan uji wilayah berganda Duncan. Analisis dilakukan dengan bantuan software SPSS 17. Selain itu juga dilakukan analisis slope dari regresi linier untuk melihat laju peningkatan kadar tiap parameter.

\section{Analisis bahan}

Analisis proksimat tahu dan tempe berdasarkan AOAC (2012). Analisis proksimat berupa kadar air (metode oven), abu (metode pengabuan kering), lemak (metode Soxhlet), protein (metode Kjedhal), karbohidrat (by difference). Analisis bilangan penyabungan dan bilangan iodin minyak awal dan kadar FFA minyak berdasarkan SNI 01-3555-1998 mengenai cara uji minyak dan lemak (BSN, 1998).

\section{Analisis kadar TPM (IUPAC, 1992)}

Kadar TPM menggunakan kromatografi kolom dan perhitungan secara gravimetri. Kolom gelas dengan diameter 2,1 cm dan panjang $35 \mathrm{~cm}$ diisi dengan 25 gram slurry silika gel. Eluen yang digunakan merupakan campuran petroleum eter (p.a) dan dietil eter (p.a) dengan rasio 87:13 (v/v). Sampel minyak 2,5 gram dimasukkan perlahan pada kolom yang telah disiapkan. Komponen non polar minyak dielusi menggunakan $150 \mathrm{~mL}$ eluen. Pelarut kemudian diuapkan. Kadar TPM dihitung berdasarkan selisih berat sampel dan berat komponen non polar.

Kadar senyawa polar $=$

$$
\frac{\text { berat sampel awal-berat non polar }}{\text { berat sampel awal }} \times 100 \%
$$

\section{Analisis spektrum FTIR}

Spektrum penyerapan minyak goreng dianalisis menggunakan alat FTIR, MB3000. Analisis dilakukan pada minyak kondisi awal, minyak setelah 15 jam penggorengan dan fraksi polar minyak goreng 15 jam penggorengan.

Komponen polar untuk analisis FTIR diperoleh dengan melakukan elusi menggunakan kolom kromatografi dari sampel minyak yang tidak ikut terelusi dengan campuran petroleum eter (p.a) dan dietil eter (p.a). Fraksi polar dielusi menggunakan dietil eter (p.a) $150 \mathrm{~mL}$.

\section{Analisis browning index (Bolade, 2017)}

Minyak goreng dianalisis menggunakan kromameter Minolta CR-400 untuk memperoleh nilai $L^{*}$, $a^{*}, b^{*}$. Browning index diperoleh melalui persamaan:

Browning Index $(\mathrm{BI})=\frac{[100(\mathrm{x}-0,31)]}{0,17} ; \mathrm{x}=\frac{\left(\mathrm{a}^{*}+1,75 \mathrm{~L}^{*}\right)}{\left(5,645 \mathrm{~L}^{*}+\mathrm{a}^{*}-3,012 \mathrm{~b}^{*}\right)}$ dimana, $\mathrm{L}=$ kecerahan $(0-100) ; \mathrm{a}=$ redness/greenness, $\mathrm{b}=$ yellowness/blueness.

\section{Analisis penyerapan spektrum spektrofotometer (Hamed et al., 2011).}

Sampel minyak diletakkan pada cuvet dan dilakukan pengukuran absorbansi (scanning) menggunakan alat spektrofotometer UV-Vis, Hitachi U-1800 pada panjang gelombang $350-650 \mathrm{~nm}$ dengan interval $10 \mathrm{~nm}$.

\section{HASIL DAN PEMBAHASAN}

\section{Karakteristik kimia bahan baku}

Hasil analisis proksimat untuk tahu diperoleh kadar air $79,91 \%$, protein $10,42 \%$, lemak 1,39\%, abu $1,19 \%$, karbohidrat 7,09\%. Tempe memiliki kadar air 65,96\%, protein 17,79\%, lemak 9,76\%, abu $0,89 \%$, karbohidrat $5,60 \%$. Hasil analisis bahan baku yang digunakan menunjukkan kadar air tahu lebih tinggi daripada tempe. Perbedaan metode pengolahan bahan pangan dapat mempengaruhi komposisi kimia suatu produk pangan. Protein pada sari kedelai dikoagulasi saat proses pembuatan tahu, sehingga sari kedelai menggumpal dan memadat menjadi tahu. Proses tersebut dapat menyebabkan tahu memiliki kadar air tinggi. Hasil analisis ini sesuai dengan hasil penelitian Midayanto dan Yuwono (2014) yang menunjukkan kadar air tahu berkisar antara 78,82-85,27\%. Tempe dibuat menggunakan biji kedelai tanpa kulitnya. Proses fermentasi menggunakan jamur $R$. oligosporus menyebabkan tempe memiliki kadar protein dan lemak tinggi (Bavia et al., 2012). Komposisi kimia atau proksimat awal bahan yang digoreng dapat memengaruhi komposisi kimia dan kualitas minyak yang digunakan menggoreng (Ghidurus et al., 2010). Kadar protein dan lemak tahu dan tempe yang digunakan dalam penelitian ini memenuhi persyaratan mutu berdasarkan SNI Tahu (BSN, 1998) dan SNI Tempe kedelai (BSN, 2015) yang menetapkan kadar protein tahu minimal $9 \%$ dan tempe minimal 15\%, sedangkan kadar lemak tahu minimal $0,5 \%$ dan tempe minimal $7 \%$.

Mutu kimia minyak goreng dianalisis sebelum digunakan untuk menggoreng dan diperoleh bilangan lodin untuk minyak kelapa 7,96 g; minyak kelapa sawit 58,56 g; minyak kedelai $125,76 \mathrm{~g}$. Bilangan iodin menunjukkan derajat ketidakjenuhan minyak dan juga tingkat kestabilan minyak terhadap oksidasi (Zahir et al., 2017). Hasil analisis bilangan iodin menunjukkan derajat ketidakjenuhan minyak kedelai $>$ minyak kelapa sawit >minyak kelapa. Derajat ketidakjenuhan tinggi menandakan sebagian besar komposisi trigliserida minyak terdiri dari asam lemak yang mempunyai ikatan rangkap. Hasil ini linier dengan kandungan asam lemak tidak jenuh pada minyak goreng kedelai sebesar $84,7 \%$, minyak kela- 
pa sawit 47,61\%, dan minyak kelapa 6\%, (Halim et al., 2016). Bilangan penyabunan minyak goreng sebelum digunakan, minyak kedelai $(189,99 \mathrm{mg})<\mathrm{mi}-$ nyak kelapa sawit $(202,40 \mathrm{mg})<$ minyak kelapa $(254,40 \mathrm{mg})$. Bilangan penyabunan yang kecil menunjukkan berat molekul rata-rata asam lemak di dalam minyak besar, yang linier dengan banyaknya ikatan rangkap (Zahir et al., 2017).

Kadar awal TPM dan FFA minyak goreng kelapa sawit $(9,55$ dan $0,09 \%)$ lebih tinggi daripada minyak kelapa $(4,44$ dan $0,06 \%)$ dan minyak kedelai (3,22 dan 0,05\%). Hasil ini serupa dengan yang diperoleh Kiran (2015). Minyak kelapa sawit mempunyai kandungan digliserida yang lebih tinggi dari minyak kedelai (Chen et al., 2013). Digliserida merupakan senyawa yang lebih polar dibandingkan trigliserida sehingga ikut terhitung sebagai TPM. Kadar FFA menunjukkan jumlah asam lemak yang tidak terikat sebagai penyusun trigliserida. Hasil analisis karakteristik kimia minyak goreng awal secara keseluruhan menunjukkan bahwa minyak goreng dalam kondisi mutu yang baik, belum terdegradasi.

\section{Kadar total polar material (TPM)}

Senyawa polar minyak goreng merupakan fraksi yang kepolarannya lebih besar dari triasilgliserol penyusunnya dan tidak terelusi oleh campuran (87:13) petroleum eter:dietil eter (Chen et al., 2013). Lama penggorengan, kombinasi jenis minyak-bahan serta interaksinya memengaruhi kadar TPM $(P<0,05)$. Setiap kombinasi jenis minyak-bahan pangan meningkat kadar TPM-nya seiring bertambahnya lama penggorengan. Semakin lama minyak digunakan menggoreng akan memengaruhi reaksi hidrolisis, oksidasi dan polimerisasi minyak goreng. Produk oksidasinya meliputi senyawa peroksida, hidroperoksida dan asam organik yang lebih polar dibandingkan dengan bentuk trigliseridanya sehingga meningkatkan kadar TPM (Fahri et al., 2015). Produk hidrolisis TAG meliputi DAG, MAG, FFA (Dobarganes dan Marques-Ruiz, 2015) yang akan semakin bertambah seiring bertambahnya lama pemakaian minyak untuk menggoreng.

Laju peningkatan kadar TPM ditunjukkan dengan slope regresi linear (Gambar 1). Minyak goreng kedelai-tempe mempunyai laju peningkatan kadar TPM paling cepat (slope tinggi). Hasil uji lanjut menunjukkan perlakuan lama penggorengan 15 jam untuk minyak kedelai-tempe mempunyai kadar TPM paling tinggi. Kadar TPM minyak goreng kedelai jam ke-0 adalah $3,22 \pm 0,37 \%$ dan pada akhir pemakaian

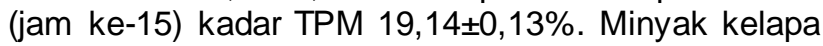
sawit meskipun memiliki kadar TPM awal tinggi $(9,55 \pm 0,05 \%)$ namun setelah dipakai 15 jam menggoreng tempe memiliki kadar TPM lebih rendah dari minyak kedelai yaitu $15,10 \pm 0,11 \%$. Perlakuan minyak kelapa-tahu dan minyak kelapa-tempe memiliki laju peningkatan kadar TPM yang lambat. Minyak kelapa memiliki nilai bilangan iodin rendah, yang berarti derajat ketidakjenuhan rendah namun stabil terhadap oksidasi (Zahir et al., 2017).

Pengaruh kombinasi minyak-bahan menunjukkan bahwa derajat ketidakjenuhan dari minyak dan jenis bahan pangan dapat memengaruhi kadar TPM minyak. Bahan yang mengandung asam lemak dengan banyak ikatan rangkap lebih mudah teroksidasi. Berdasarkan Li et al. (2017) kandungan senyawa polar mempunyai korelasi tinggi dengan kadar C18: 2 minyak goreng. Asam linoleate banyak terdapat di dalam tempe disebabkan adanya proses fermentasi kedelai yang meningkatkan jumlah asam lemak tidak jenuh terutama asam linoleat (Triwibowo et al., 2016).

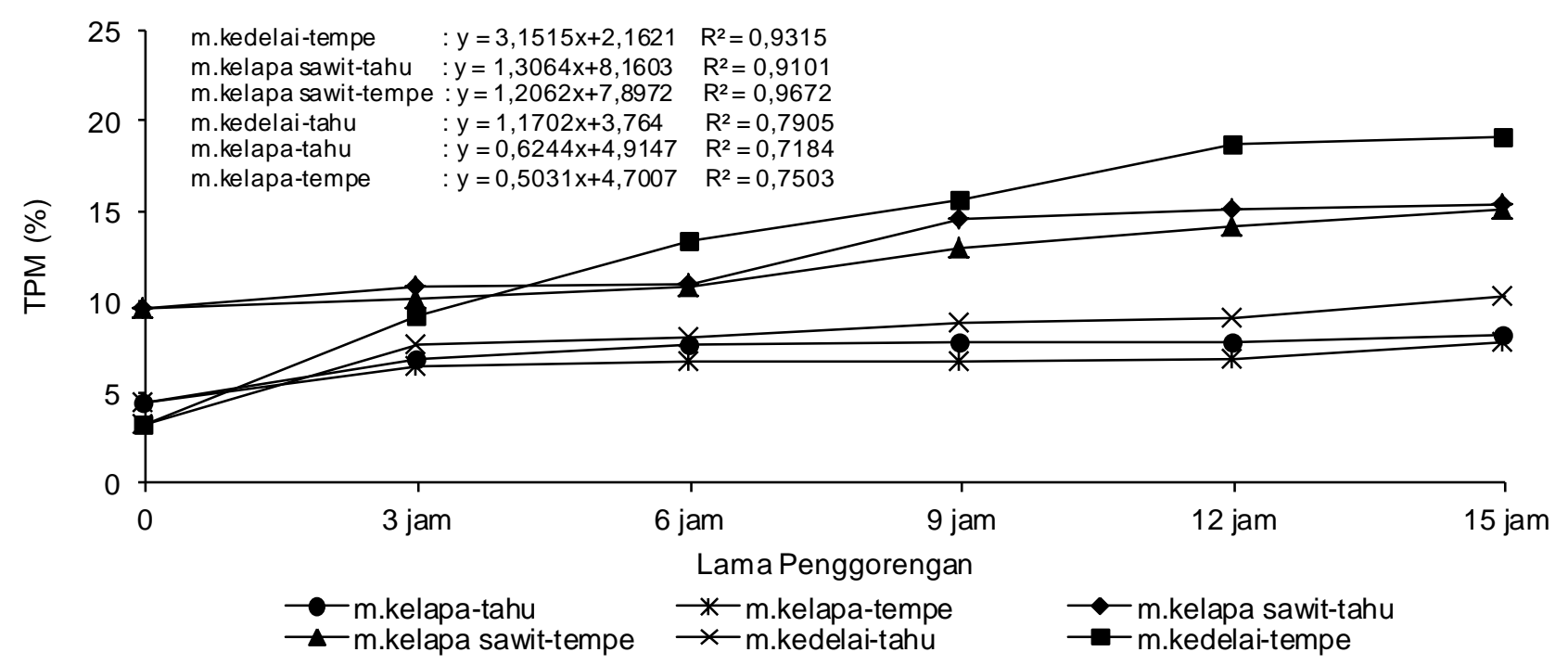

Gambar 1. Profil kadar TPM minyak goreng 
Minyak kedelai mengandung sejumlah besar asam linoleat yang sangat mudah teroksidasi (Chen et al., 2013). Kombinasi keduanya menyebabkan kandungan asam linoleat menjadi lebih tinggi dibandingkan kombinasi lainnya sehingga seiring bertambah lama pemakaian minyak menyebabkan reaksi oksidasi dapat lebih cepat terjadi dan meningkatkan kadar TPM. Minyak yang kaya asam linoleat juga lebih mudah terjadi polimerisasi selama penggorengan menghasilkan produk seperti TAG dimer dan polimer sehingga kadar TPM meningkat (Nayak et al., 2015).

Meskipun kadar TPM semua perlakuan kombinasi jenis minyak goreng-bahan pangan yang digunakan sampai 15 jam menunjukkan peningkatan namun belum melampaui kadar 24-27\%, sebagai batasan kadar TPM yang ditetapkan oleh beberapa negara Eropa (Li et al., 2016). Setiap pengambilan sampel pada penelitian ini dilakukan penambahan minyak baru untuk mempertahankan rasio (bahan: minyak) sehingga degradasi minyak dapat diperlambat (Choe dan Min, 2007).

\section{Profil spektrum absorbansi minyak goreng kede- lai dengan FTIR}

Parameter kadar TPM menunjukkan bahwa minyak kedelai lebih cepat terdegradasi dibandingkan minyak kelapa dan kelapa sawit sehingga dilakukan analisis FTIR hanya pada minyak kedelai. Analisis spektrum FTIR minyak kedelai memperlihatkan pita penyerapan yang khas pada trigliserida (Gambar 2). Jumlah asam lemak penyusun minyak dapat memengaruhi posisi pita spektrum dan pergeserannya (Zahir et al., 2017). Tabel 1 memperlihatkan spektrum yang terdeteksi pada minyak kedelai awal, minyak kedelai-tahu 15 jam, minyak kedelai-tempe 15 jam.

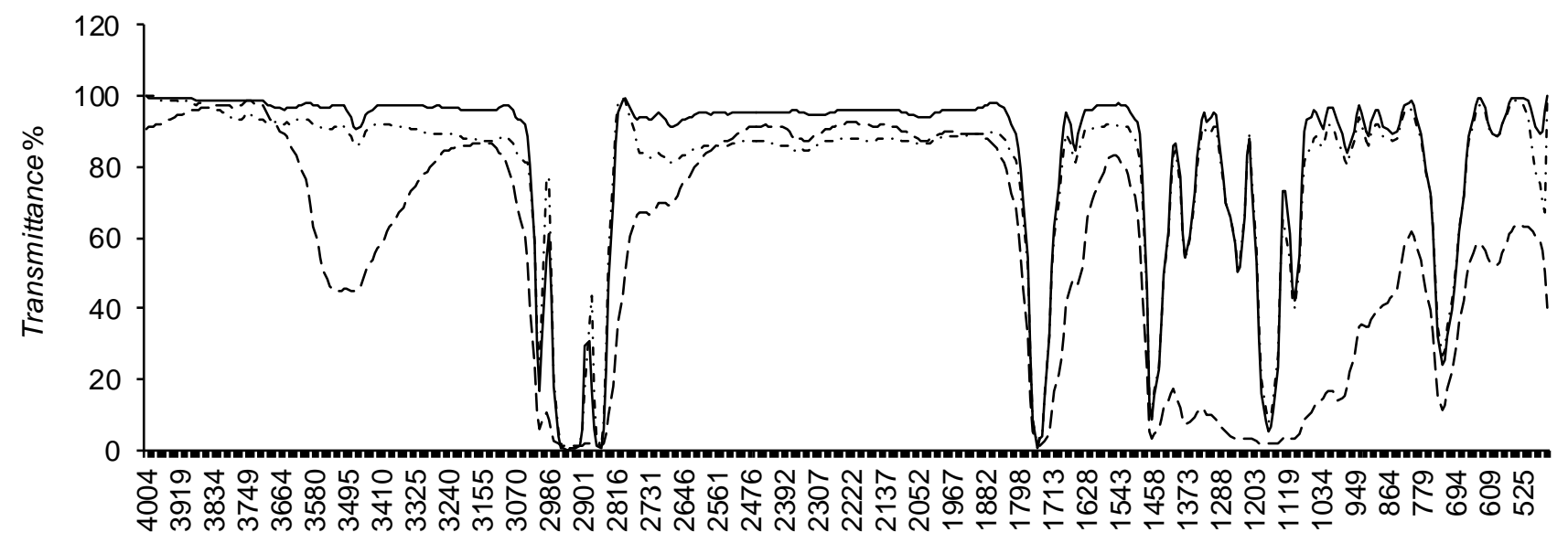

Wavenumbercm-1

- M.Kedelai (awal)

-.... M.Kedelai-Tahu (15 jam)

- - Polar (M.Kedelai-Tahu)

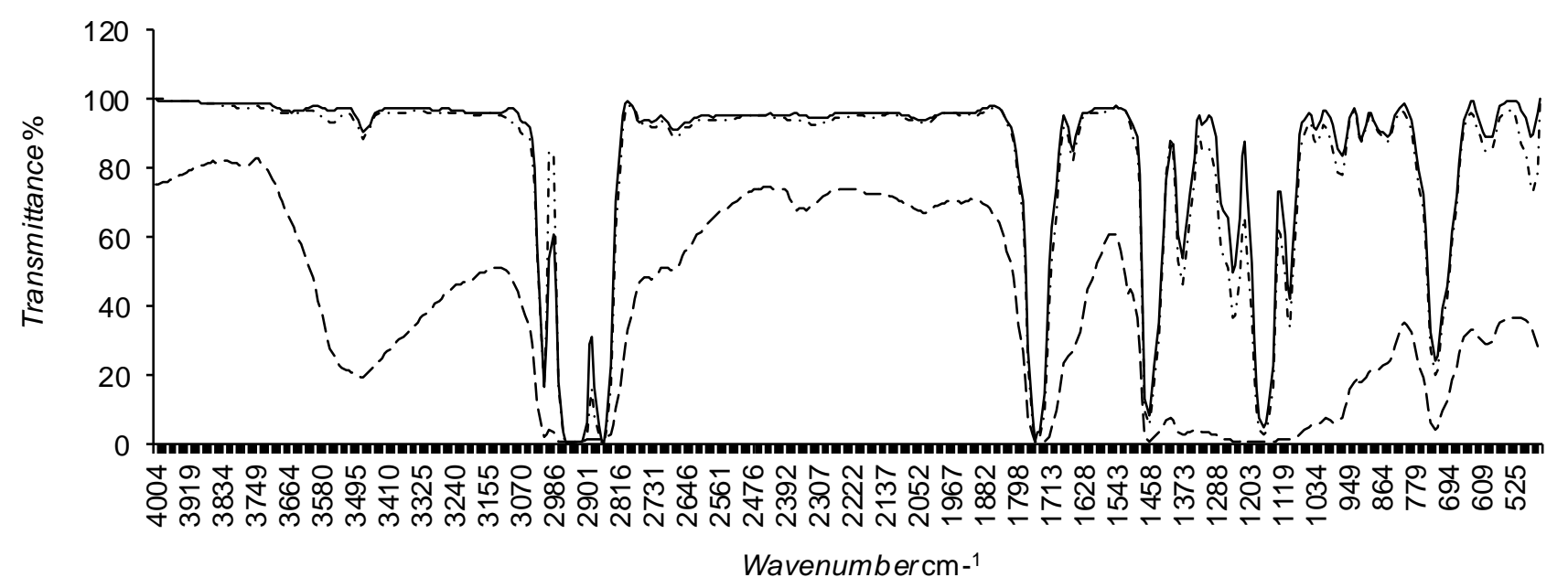

M.Kedelai (awal)

-.... M.Kedelai-Tempe (15 jam)

- Polar (M.Kedelai-Tempe)

Gambar 2. Profil spektrum FTIR minyak goreng 
Tabel 1. Spektrum FTIR minyak goreng kedelai (Vlachos, 2006; Zahir, 2017)-

\begin{tabular}{|c|c|}
\hline \multicolumn{2}{|c|}{ 1. Daerah Gugus Fungsi } \\
\hline \multicolumn{2}{|c|}{ 1a. Daerah Peregangan Hydrogen } \\
\hline $\begin{array}{l}3472 \mathrm{~cm}^{-1} \\
3009 \mathrm{~cm}^{-1} \\
2854 \mathrm{~cm}^{-1}\end{array}$ & $\begin{array}{l}\text { Gugus } \mathrm{OH} \text { dari hidroperoksida } \\
\mathrm{C}-\mathrm{H} \text { dari cis ikatan rangkap }(=\mathrm{C}-\mathrm{H}) \\
\mathrm{C}-\mathrm{H} \text { asimetri dan simetri dari } \mathrm{CH}_{2} \\
\text { alifatik }\end{array}$ \\
\hline \multicolumn{2}{|c|}{ 1b. Daerah Peregangan Ikatan Rangkap } \\
\hline $\begin{array}{c}1751 \mathrm{~cm}^{-1} \\
1743 \mathrm{~cm}^{-1} \\
1643 \mathrm{~cm}^{-1} \\
1651 \mathrm{~cm}^{-1} \\
\end{array}$ & $\begin{array}{l}\text { Gugus } \mathrm{C}=\mathrm{O} \text { dari ester, aldehid, } \\
\text { keton } \\
\mathrm{C}=\mathrm{C} \text { dari cis-olefins }\end{array}$ \\
\hline \multicolumn{2}{|c|}{$\begin{array}{l}\text { 1c. Daerah Perubahan Bentuk dan Pembengkokan } \\
\text { Ikatan Lainnya }\end{array}$} \\
\hline $\begin{array}{l}1458 \mathrm{~cm}^{-1} \\
1373 \mathrm{~cm}^{-1}\end{array}$ & $\begin{array}{l}\mathrm{CH}_{2} \text { dan } \mathrm{CH}_{3} \text { alifatik } \\
\mathrm{CH}_{2}\end{array}$ \\
\hline \multicolumn{2}{|c|}{ 2. Daerah Fingerprint (Sidik Jari) } \\
\hline $\begin{array}{c}1165 \mathrm{~cm}^{-1} \\
964 \mathrm{~cm}^{-1} \\
980 \mathrm{~cm}^{-1} \\
725 \mathrm{~cm}^{-1}\end{array}$ & $\begin{array}{l}\mathrm{C}-\mathrm{O} \\
\text { Trans ikatatan rangkap }(\mathrm{CH}=\mathrm{CH})\end{array}$ \\
\hline
\end{tabular}

Terlihat pita penyerapan spektrum yang besar pada $3.009 \mathrm{~cm}^{-1}$ yang menunjukkan adanya asam linoleat (Vlachos et al., 2006). Spektrum FTIR minyak kedelai-tahu dan minyak kedelai-tempe mengalami peningkatan persentase transmitan (\%T) pada sebagian besar puncak pita spektrum yang mungkin disebabkan hidrolisis dan oksidasi minyak selama penggorengan. Spektrum minyak penggo-

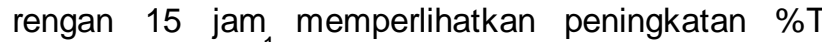
pada $3.009 \mathrm{~cm}^{-1}$ menandakan berkurangnya jumlah cis ikatan rangkap. Hal ini sejalan dengan penurunan \%T pada daerah $964-980 \mathrm{~cm}^{-1}$ menunjukkan terbentuknya trans ikatan rangkap. Tena et al. (2014) menyatakan daerah infrared optimum pada minyak virgin olive untuk memprediksi adanya TPM dari minyak yang teroksidasi adalah $978-960 \mathrm{~cm}^{-1}$. Daerah $1.751 \mathrm{~cm}^{-1}$ mengalami perubahan penyerapan lebih banyak pada minyak kedelai-tempe. Jumlah gugus karbonil $(\mathrm{C}=\mathrm{O})$ yang semakin bertambah menandakan adanya senyawa aldehid dan keton yang mungkin terbentuk akibat minyak terdegradasi (Vlachos et al., 2006).

Spektrum FTIR fraksi polar terlihat pita penyerapan produk oksidasi sekunder pada daerah 1736 dan $1744 \mathrm{~cm}^{-1}$. Tena et al. (2014) menyatakan perubahan penyerapan pada $1780-1670 \mathrm{~cm}^{-1}$ khususnya pada puncak $1743 \mathrm{~cm}^{-1}$ dapat menunjukkan terjadinya hidrolisis trigliserida, namun tidak dapat memastikan gugus $\mathrm{C}=\mathrm{O}$ sebagai pengurangan dari ester atau penambahan akibat adanya asam lemak bebas (sebagai asam karboksilat).

Spektrum FTIR fraksi polar minyak goreng terlihat tajam dan lebar pada daerah $3700-3100 \mathrm{~cm}^{-1}$ dengan puncak pada daerah $3472 \mathrm{~cm}^{-1}$. Puncak penyerapan tersebut menunjukkan adanya first over- tone gugus ester dari trigliserida. Pada bilangan gelombang lebih tinggi (spektrum menurun) menunjukkan adanya gugus hidroksil (stretching $\mathrm{OH}$ ) yang dapat menunjukkan bahwa minyak goreng telah bertambah kepolarannya (Tena et al., 2014). Semakin banyak ditemukan gugus hidroksil maka semakin polar minyak tersebut. Penyerapan yang besar pada fraksi polar minyak kedelai-tempe linier dengan hasil yang diperoleh pada analisis kadar TPM-nya.

\section{Kadar asam lemak bebas (FFA)}

Asam lemak bebas atau free fatty acid (FFA) terbentuk dari hidrolisis ikatan ester pada trigliserida selama penggorengan. Kadar FFA minyak kelapa dinyatakan sebagai jumlah asam laurat yang bebas selama penggorengan berlangsung. Kadar FFA minyak kelapa sawit sebagai asam palmitat dan minyak kedelai sebagai asam oleat. Perlakuan kombinasi minyak-bahan pangan dan lama pemakaian minyak goreng serta interaksinya mempengaruhi kadar FFA $(P<0,05)$. Kadar FFA setiap kombinasi jenis minyak-bahan pangan meningkat seiring dengan bertambahnya lama pemakaian minyak untuk menggoreng.

Laju peningkatan kadar FFA dilihat dari slope regresi linear (Gambar 3) memperlihatkan bahwa ketiga jenis minyak yang digunakan menggoreng tempe memiliki laju peningkatan FFA lebih tinggi dibandingkan ketiga jenis minyak untuk menggoreng tahu. Hal ini menunjukkan pembentukan FFA dipengaruhi karakteristik bahan yang digoreng. Hasil ini juga sesuai yang diperoleh Kiran (2015) dimana pembentukan FFA lebih tinggi pada minyak kelapa sawit dan minyak kedelai yang digunakan selama 10 jam (20 siklus penggorengan) untuk menggoreng nugget ayam dibandingkan untuk menggoreng kentang dan minyak yang hanya dipanaskan tanpa bahan pangan.

Hidrolisis trigliserida diinisiasi oleh adanya air dari bahan yang digoreng. Kadar air tinggi akan mempercepat hidrolisis menghasilkan DAG, MAG, FFA, gliserol (Tarmizi, 2016). Tahu memiliki kadar air lebih tinggi dibandingkan tempe. Namun hasil penelitian ini menunjukkan pembentukan FFA lebih cepat pada ketiga jenis minyak untuk menggo-reng tempe. Berdasarkan Sundari et al. (2015), tempe setelah digoreng mengalami penyusutan kadar air sebesar 20,13\% sedangkan pada tahu hanya $7,66 \%$. Penyusutan kadar air bahan pangan selama penggorengan terjadi karena selama penggorengan air keluar dari bahan pangan. Struktur dan matriks tahu lebih rapat dibandingkan tempe sehingga pada penggorengan dengan waktu yang sama, air terikat pada tempe lebih cepat keluar dan lebih banyak yang berpindah ke dalam minyak goreng (Bordin et al., 2013). Hal ini memungkinkan lebih banyak terjadi hidrolisis pada minyak yang digunakan menggoreng tempe. 


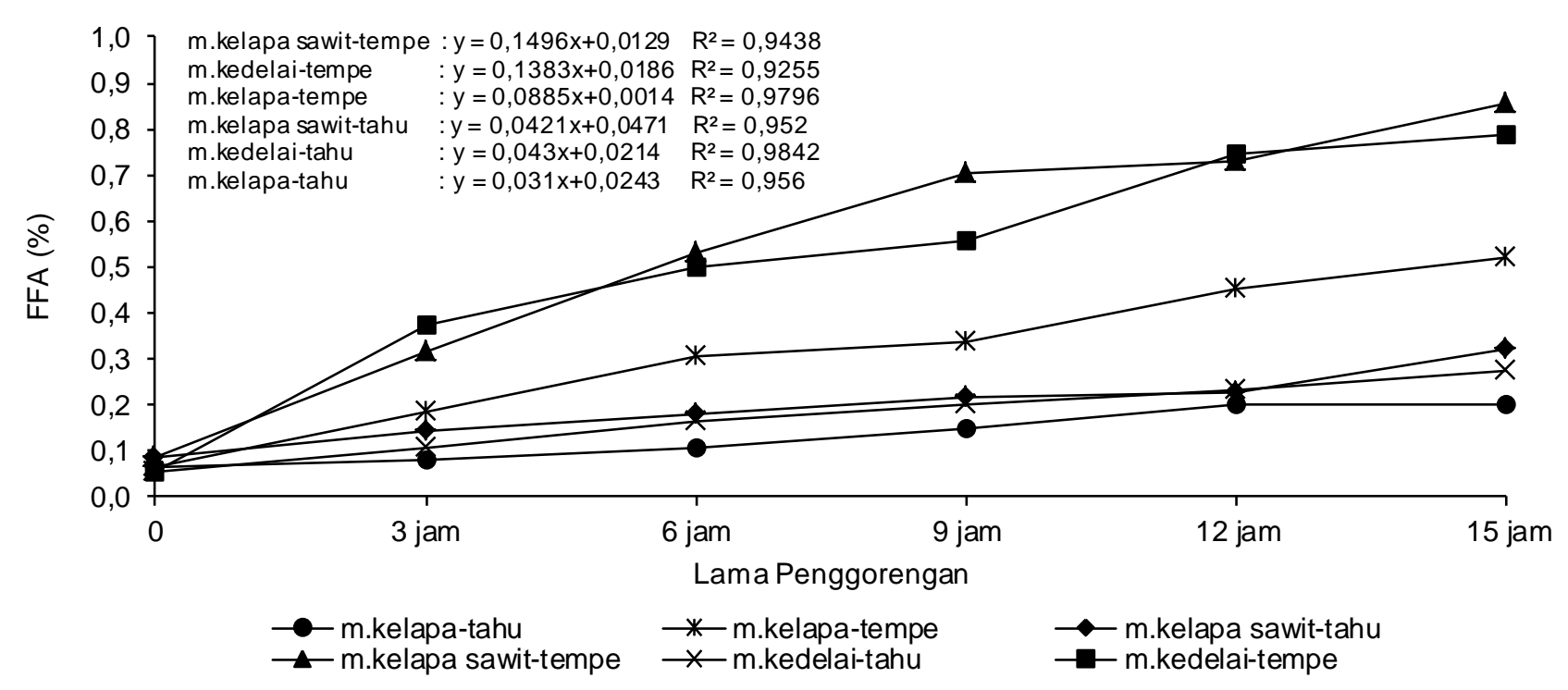

Gambar 3. Profil kadar FFA minyak goreng

Kadar FFA selama penggorengan bukan hanya dipengaruhi oleh kadar air tahu dan tempe, karena air yang keluar dari bahan pangan cepat menguap seiring naiknya suhu penggorengan sehingga tidak semua air bahan pangan menghidrolisis minyak goreng (Chen et al., 2013). Kandungan lemak dan asam lemak tidak jenuh bahan pangan dapat memengaruhi jumlah asam lemak dalam minyak goreng melalui proses transfer massa antara bahan pangan dan minyak goreng (Tarmizi, 2016). Tahu dan tempe merupakan bahan pangan yang tinggi kandungan asam lemak tidak jenuhnya. Berdasarkan Damasio et al. (2013) tahu memiliki kandungan PUFA 56,57$60,33 \%$, MUFA $23,9-25,04 \%$ (asam oleat 21,74$22,65 \%$ ) dan SFA $15,77-17,27 \%$ (asam palmitat 10,74-12,26\%). Tempe merupakan bahan pangan yang tinggi kandungan asam lemak tidak jenuh. Selama proses fermentasi tempe kedelai ter-jadi hidrolisis lemak kedelai oleh kapang menghasil-kan asam lemak bebas. Kandungan asam lemak pa-da tempe yang utama yaitu asam palmitat $(7,21 \%)$, stearat, oleat $(14,74 \%)$, linoleate $(50,12 \%)$ dan linolenat (Utari, 2010). Selama penggorengan, asam lemak pada tahu maupun tempe dapat bermigrasi ke dalam minyak. Lemak pada tahu dan tempe juga dapat terhidrolisis selama penggorengan menghasilkan FFA yang bila bermigrasi ke dalam minyak turut menambah kadar FFA minyak (Sutanto et al., 2016). Kadar lemak tempe lebih tinggi daripada tahu sehingga kemungkinan lebih banyak FFA dari tempe yang bermigrasi ke dalam minyak.

Laju peningkatan kadar FFA minyak kelapa sawit>minyak kedelai>minyak kelapa, baik untuk menggoreng tempe maupun tahu. Hasil serupa juga diperoleh oleh Kiran (2015) yang menyatakan kadar FFA minyak kelapa sawit lebih tinggi dari minyak kedelai pada akhir penggorengan. Komposisi asam le- mak pada minyak mempengaruhi jumlah dan jenis asam lemak bebas yang terbentuk pada reaksi hidrolisis minyak goreng (Mariana et al., 2014). Minyak kelapa sawit memiliki kandungan asam palmitat dan asam oleat lebih tinggi daripada minyak kedelai yang lebih kaya asam linoleat (Nayak et al., 2015). Hal ini memengaruhi laju pembentukan FFA minyak kelapa sawit lebih cepat dibandingkan minyak ke-delai.

Analisis uji lanjut menunjukkan kadar FFA tertinggi pada minyak kelapa sawit-tempe pemakaian 15 jam $(0,85 \pm 0,08 \%)$ namun tidak berbeda signifikan $(P \geq 0,05)$ dengan minyak kedelai-tempe 15 jam $(0,78 \pm 0,01 \%)$. Hasil analisis kadar FFA ini memiliki hasil lebih rendah dibandingkan dengan Halim et al. (2016) dengan pemakaian minyak selama 2 jam tanpa penambahan minyak baru. Penambahan minyak baru selama penggorengan untuk mempertahankan rasio bahan:minyak dapat memperlambat reaksi hidrolisis dan terbentuknya asam lemak bebas (Choe dan Min, 2007).

\section{Profil browning index (BI) minyak goreng}

Perubahan tingkat warna coklat minyak goreng dinyatakan dengan nilai browning index (BI). Hasil analisis menunjukkan perlakuan kombinasi minyakbahan dan waktu penggorengan serta interaksinya mempengaruhi $(P<0,05)$ nilai $\mathrm{BI}$. Setiap jenis minyak yang digunakan menggoreng tahu maupun tempe meningkat nilai BI-nya yang berarti warna minyak semakin coklat seiring bertambahnya lama pemakaian minyak. Laju peningkatan BI ditunjukan dengan slope regresi linear (Gambar 4) dengan perlakuan minyak kedelai-tempe memiliki laju tertinggi. Peningkatan paling cepat ini juga dapat dilihat dari BI jam ke-0 minyak kedelai $(1,87)$, minyak kelapa sawit $(4,16)$, minyak kelapa $(1,41)$. Sesuai hasil uji lanjut 
pada jam ke-15 minyak kedelai-tempe mempunyai nilai $\mathrm{Bl}$ tertinggi yaitu $28,38 \pm 0,35$. Nilai $\mathrm{BI}$ minyak kelapa sawit saat awal paling tinggi namun pada jam ke-15 setelah menggoreng tempe nilai BI-nya $(24,11 \pm 2,87)$, lebih rendah dari minyak kedelai.

Minyak menjadi lebih coklat karena kontribusi produk hasil reaksi Maillard selama penggorengan dan berpindahnya pigmen dari bahan pangan ke minyak (Aminah, 2010). Minyak menggoreng tempe lebih cepat berubah coklat karena reaksi Maillard pada tempe selama penggorengan. Reaksi Maillard terjadi antara gula pereduksi dan asam amino bebas menghasilkan pigmen melanoidin berwarna coklat (Mariana, 2014). Kadar protein tahu dan tempe hampir sama, namun tempe memiliki kandungan asam amino dan gula pereduksi tinggi. Proses fermentasi kedelai menjadi tempe meningkatkan kadar asam amino (Rahmi et al., 2018). Kedelai yang difermentasi mempunyai kadar gula reduksi lebih tinggi dibandingkan tanpa fermentasi (Andarti et al., 2015). Semakin banyak kandungan asam amino dan gula pereduksi pada bahan yang terpapar panas maka akan lebih mudah terjadi reaksi Maillard sehingga produk akan berwarna kecoklatan. Pigmen coklat ini dapat teradsorbsi ke dalam minyak sehingga minyak terlihat semakin coklat (Bolade et al., 2017).

Selain pengaruh dari bahan yang digoreng, perubahan warna minyak semakin coklat juga dipengaruhi oleh reaksi oksidasi termal pada minyak goreng seiring dengan bertambah lama waktu pemakaian minyak. Penampakan minyak yang menjadi lebih gelap disebabkan adanya senyawa non volatile hasil degradasi seperti polimer dan trigliserida teroksidasi (Nayak et al., 2015).

\section{Profil absorbansi minyak goreng dengan spek- trofotometer UV-Vis}

Hasil scanning minyak goreng pada 350-650 $\mathrm{nm}$ menunjukkan semakin lama waktu penggorengan terjadi perubahan absorbansi (efek hiperkromik) dan pergeseran panjang gelombang (batokromik), dengan puncak absorbansi terlihat pada $420 \mathrm{~nm}$. Penelitian Hamed et al. (2011) menunjukkan hasil yang berbeda dimana absorbansi tertinggi pada 393 $\mathrm{nm}$. Jenis bahan pangan dan jenis minyak yang digunakan dapat memengaruhi degradasi yang terjadi. Pergeseran batokromik dan efek hiperkromik lebih ekstrem terjadi pada minyak goreng yang digunakan untuk menggoreng tempe.

Semua perlakuan menunjukkan peningkatan absorbansi minyak pada $420 \mathrm{~nm}$ seiring bertambah lama penggorengan dengan laju tertinggi pada perlakuan kombinasi minyak kedelai-tempe, yang menunjukkan degradasi lebih cepat terjadi pada minyak kedelai untuk menggoreng tempe. Hasil ini linier dengan analisis kadar TPM sehingga kemungkinan pada panjang gelombang $420 \mathrm{~nm}$ terdapat senyawa hasil degradasi minyak goreng yang bersifat polar. Karayaka dan Simsek (2011) menyatakan bahwa perubahan spektrum mempunyai korelasi dengan kadar TPM minyak goreng. Semakin banyak senyawa yang memiliki gugus karbonil $(\mathrm{C}=\mathrm{O})$ di dalam minyak dapat mengindikasikan terdapatnya senyawa karboksilat, aldehid, keton sebagai produk degradasi minyak .

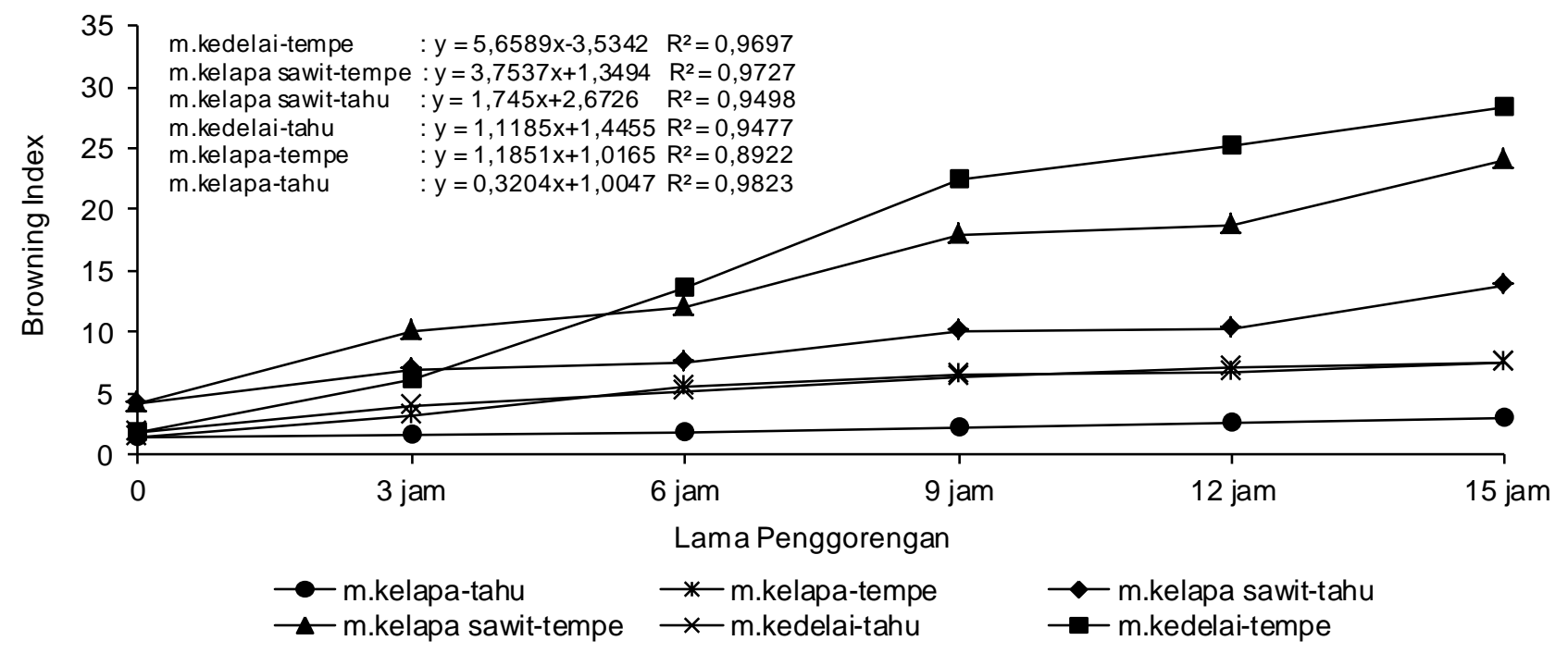

Gambar 4. Profil indeks warna coklat (BI) minyak goring 


\section{KESIMPULAN}

Jenis minyak goreng serta jenis bahan yang digoreng mempengaruhi profil pembentukan senyawa polar yang terlihat dari peningkatan TPM, FFA, BI seiring bertambah lama waktu penggorengan. Kombinasi minyak kedelai-tempe menghasilkan kadar TPM paling tinggi dan laju pembentukan senyawa polar paling cepat sampai 15 jam penggorengan. Produk sumber protein nabati yang difermentasi yaitu tempe menghasilkan kadar TPM dan FFA tinggi pada minyak yang digunakan menggoreng. Kombinasi minyak kelapa-tahu memiliki laju pembentukan senyawa polar paling lambat. Hasil analisis spektrum dengan UV-Vis dan FTIR dapat membantu menunjukkan terjadinya degradasi minyak goreng khususnya pembentukan senyawa polar.

\section{DAFTAR PUSTAKA}

Aminah S. 2010. Bilangan peroksida minyak goreng curah dan sifat organoleptik tempe pada pengulangan penggorengan. J Pangan Gizi 3: 7-14.

Andarti IY, Wardani AK. 2015. Pengaruh lama fermentasi terhadap karakteristik kimia, mikrobiologi, dan organoleptik miso kedelai hitam (Glycine max (L). J Pangan Agroind 3: 889-898.

[AOAC] Association of Official Analytical Chemistry. 2012. Official Methods of Analysis of the Association of Official Analytical Chemistry. Maryland (US): AOAC.

Bavia ACF, Silva CE, Ferreira MP, Leite RS, Mandarino JMG, Carrao-Panizzi MC. 2012. Chemical composition of tempeh from soybean cultivars specially developed for human consumption. Ciênc Tecnol Aliment 32: 613-620. DOI: $10.1590 /$ S0101-20612012005000085.

Bolade MK, Usman MA, Da-Clarke U. 2017. Proximate composition, colour characteristics, index of oiliness and estimated glycemic index of deep-fried bitter yam (Dioscorea dumentorum) chips. Int J Sci 6: 39-47. DOI: 10.18483/ijSci. 1468.

Bordin K, Kunitake MT, Aracava KK, Trindade CS. 2013. Changes in food caused by deep fat frying - a review. Arch Latinoam Nutr 63: 5-13.

[BPS] Badan Pusat Statistik. 2018. Rata-Rata Konsumsi per Kapita Seminggu Beberapa Macam Bahan Makanan Penting, 2007-2017. http:// www.bps.go.id. [11 Mei 2018]

[BSN] Badan Standardisasi Nasional. 1998. SNI Cara Uji Minyak dan Lemak. Jakarta (ID): BSN

[BSN] Badan Standardisasi Nasional. 1998. SNI Tahu. Jakarta (ID): BSN
[BSN] Badan Standardisasi Nasional. 2015. SNI Tempe kedelai. Jakarta (ID): BSN

Chen W, Chiu C, Cheng W, Hsu C, Kuo M. 2013. Total polar compounds and acid values of repeatedly used frying oils measured by standard and rapid methods. J Food Drug Anal 21: 5865. DOI: 10.6227/jfda.2013210107.

Choe E, Min DB. 2007. Chemistry of deep fat frying oils: concise reviews in food science. J Food Sci 72: 77-86. DOI: 10.1111/j.1750-3841.2007. 00352.x.

Damasio JMA, Requiao LA, Santana DA, Silva MV, Souza NE, Coro FAG, Simionato Jl. 2013. Lipid stability of soybeans in grains and soybeans processed as tofu. J Agric Sci 5: 67-74. DOI: 10.5539/jas.v5n11p67.

[DGF] Deutsche Gesellschaft für Fettwissenschaft. 2013. Recommendation of symposium. The 7th International Symposium on Deep-Fat Frying: 20-22 February 2013, San Fransisco, CA, USA. http//www.dgfett.de/material/recomm.php. [12 Mei 2017].

Dobarganes C, Marquez-Ruiz G. 2015. Possible adverse effects of frying with vegetable oils. British J Nutr 113: 49-57. DOI: 10.1017/S000711 4514002347.

Fahri Y, Onur O, Ozge O. 2015. Changes in quality characteristics of different deep frying fats during frying and regeneration potentials of different adsorbents in wasted frying oils. J Food Nutr Res 3: 176-181. DOI: 10.12691/jfnr-3-3-8.

Fan HY, Sharifudin MS, Hasmadi M, Chew HM. 2013. Frying stability of rice bran oil and palm oilen. Int Food Res J 20: 403-407.

Ghidurus M, Turtoi M, Boskou G, Niculita P, Stan V. 2010. Nutritional and health aspects related to frying (I) - a review. Rom Biotech Lett 15: 56755682.

Halim Y, Natania, Halim JM, Soedirga LC, Yakhin LA. 2016. Physical and chemical characteristics of frying oil in Indonesia in a repeated frying model. J Chem Pharm Res 8: 583-589.

Hamed SF, El-Wafa GA, El-Ghorab A, Shibamoto T. 2011. Quality assessment of heated cooking oil, agab, using a simple newly-developed spectrophotometric method. J Am Oil Chem Soc 88: 1851-1855. DOI: 10.1007/s11746-011-1859-z.

Hashem HA, Shahat M, El-Behairy SA, Sabry A. 2017. Use of palm olein for improving the quality properties and oxidative stability of some vegetable oils during frying process. Middle East $\mathrm{J}$ Appl Sci 7: 68-79.

[IUPAC] International Union of Pure and Applied Chemistry. 1992. Standard Methods for the Analysis of Oils, Fats and Derivatives. $7^{\text {th }} \mathrm{Ed}$. 
Determination of Polar Compounds in Frying Fats. Oxford (GB): Pergamon Press.

Karayaka S, Simsek S. 2011. Changes in total polar compounds, peroxide value, total phenols and antioxidant activity of various oils used in deep fat frying. J Am Oil Chem Soc 88: 1361-1366.

Kiran CR. 2015. Thermal Degradation Studies on Edible Oils During Deep Fat Frying Process [Tesis]. Kerala: Interdisciplinary Science and Technology (CSIR), Agroprocessing and Natural Products Division of National Institute, India.

Koh SP, Long K. 2012. Oxidative stability study of virgin coconut oil during deep frying. J Trop. Agric Food Sci 40: 35-44.

Li J, Li X, Cai W, Liu Y. 2016. Comparison of different polar compounds induced cytotoxicity in human hepatocellular carcinoma HepG2 cells. Lipids in Health and Disease 15: 30. DOI: 10.11 86/s12944-016-0201-z.

Li X, Li J, Wang JLY, Cao P, Liu Y. 2017. Effects of frying oils' fatty acids profile on the formation of polar lipids components and their retention in French fries over deep-frying process. Food Chem 237: 98-105. DOI: 10.1016/j.foodchem.2 017.05.100

Mariana RR, Kirana TM, Hidayati L. 2014. Analysis on the quality change of tempeh, catfish and fried chicken as the effect of the repetitive used cooking oil. J Food Res 3: 96-104. DOI: 10. 5539/jfr.V3n1 p96.

Midayanto DN, Yuwono SS. 2014. Penentuan atribut mutu tekstur tahu untuk direkomendasikan sebagai syarat tambahan dalam standar nasional Indonesia. J Pangan Agroind 2: 259-267.

Nayak PK, Dash U, Rayaguru K, Krishnan KR. 2015. Physio-chemical changes during repeated frying of cooked oil: a review. J Food Biochem 40: 371-390. DOI: 10.1111/jfbc. 12215.

Rahmi SL, Mursyid, Wulansari D. 2018. Formulasi tempe berbumbu serta pengujian kandungan gizi. J Teknol Manajemen Agroind 7: 57-65. DOI: 10.21776/ub.industria.2018.007.01.7.
Rizkaprilisa W, Setiadi. 2018. Comparative study of $\mathrm{CaSO}_{4}$ and papain enzyme as coagulants in the tofu production. Indonesian Food Nutr Progr 15: 79-84. DOI: 10.22146/ifnp.33349.

Sundari D, Almasyhuri, Lamid A. 2015. Pengaruh proses pemasakan terhadap komposisi zat gizi bahan pangan sumber protein. Media Litbangkes 25: 235-242. DOI: $10.22435 / \mathrm{mpk} . \mathrm{v} 25 \mathrm{i} 4.45$ 90.235-242.

Sutanto S, Rahman R, Abriana A. 2016. Pengaruh pengulangan penggorengan terhadap kandungan asam lemak bebas dan viskositas minyak hasil penggorengan. J Ecosystem 16: 498-514.

Tabee E, Jagerstad M, Dutta P. 2009. Frying quality characterictics of french fries prepared in refined olive oil and palm olein. J Am Oil Chem Soc 86: 885-893. DOI: 10.1007/s11746-009-1417-0.

Tarmizi AAH, Ismail R, Kuntom A. 2016. Effect of frying on the palm oil quality attributes - a review. J Oil Palm Res 28: 143-153.

Tena NR, Aparicio-Ruiz R, Garcia-Gonzalez DL. 2014. Use of polar and nonpolar fractions as additional information sources for studying thermoxidized virgin olive oils by FTIR. Grasas Aceites 65: 30. DOI: 10.3989/gya.121913.

Triwibowo R, Andriani MAM, Ariviani S. 2016. Perubahan biokimiawi stakiosa dan asam lemak esensial pada tempe kedelai (Glycine max) selama proses fermentasi. Bioteknologi 13: 34-41.

Utari DM. 2010. Kandungan asam lemak, zinc, dan copper pada tempe, bagaimana potensinya untuk mencegah penyakit degeneratif. Gizi Indon 33: 108-115.

Vlachos N, Skopelitis Y, Psaroudaki M, Konstantinidou V, Chatzilazarou A, Tegou E. 2006. Applications of Fourier transform-infrared spectroscopy to edible oils. Anal Chim Acta 573-574: 459-465. DOI: 10.1016/j.aca.2006.05.034.

Zahir E, Saeed R, Hameed MA, Yousuf A. 2017. Study of physicochemical properties of edible oil and evaluation of frying oil quality by Fourier Transform-Infrared (FT-IR) Spectroscopy. J Arab Chem 10: S3870-S3876. DOI: 10.1016/j. arabjc.2014.05.025. 